\title{
Effect of Preoperative Anti Tuberculosis Drug Administration Duration on Tuberculous Spondylitis Surgical Treatment Outcomes
}

\author{
Preodita Agradi, Nucki Nursjamsi Hidajat, Ahmad Ramdan \\ Department of Orthopaedic and Traumatology Faculty of Medicine Universitas Padjadjaran/ \\ Dr. Hasan Sadikin General Hospital Bandung
}

\begin{abstract}
Preoperative anti-tuberculosis (TB) drugs play a role in surgery of TB spondylitis patients to prevent transmission in the operating room, reduce inflammatory processes and prevent relapse. Currently, there is no study on effects of preoperative anti TB drugs administration duration on the spinal TB patients surgical outcome at Dr. Hasan Sadikin General Hospital (RSHS). This study used retrospective method by analyzing medical record data of TB spondylitis patients operated at RSHS, January 2014-May 2018. Based on the preoperative TB drugs duration, patients were divided into 2 groups: preoperative TB drugs group $<2$ and 2-4 weeks. Data analyzed were identity, duration of preoperative TB drugs administration, preoperative neurologic grade, preoperative CRP and ESR level, and postoperative data at 2 month follow up consisted of neurologic grade, postoperative CRP and ESR levels. The 58 patients consisted of 25 males and 33 females, Kolmogorov-Smirnov test showed a significant difference $(\mathrm{p}<0.05)$ in postoperative neurologic grade between preoperative TB drugs administration $<2$ vs $2-4$ weeks. Unpaired T-Test showed postoperative CRP and ESR levels were significant $(\mathrm{p}<0.05)$. Postoperative neurologic grade in the preoperative TB drugs $<2$ weeks group was better vs the $2-4$ week group. Operative procedure is more important in TB spondylitis patients treatment compared to a prolonged preoperative TB drugs administration.
\end{abstract}

Key words: C-reactive protein (CRP), erythrocyte sedimentation rate (ESR), preoperative TB drugs

\section{Pengaruh Lama Pemberian Obat Anti Tuberkulosis Preoperatif Terhadap Hasil Pengobatan Spondilitis Tuberkulosis yang Mengalami Tindakan Operatif}

\begin{abstract}
Abstrak
Obat anti tuberkulosis (OAT) preoperatif memiliki peranan penting dalam pembedahan pasien spondilitis tuberkulosis sebagai pencegahan penularan di kamar operasi, menurunkan proses inflamasi, dan mencegah relaps. Sampai saat ini belum terdapat penelitian mengenai pengaruh lama pemberian OAT preoperatif terhadap hasil pembedahan pasien spondilitis tuberkulosis di Rumah Sakit Dr. Hasan Sadikin Bandung (RSHS). Penelitian ini menggunakan metode retrospektif dengan menganalisisa data rekam medis pasien spondilitis tuberkulosis yang dioperasi di RSHS periode Januari 2014-Mei 2018. Berdasar atas lama pemberian OAT preoperatif, sampel dibagi menjadi 2 kelompok, yaitu kelompok pemberian OAT preoperatif $<2$ dan 2-4 minggu. Data yang dianalisis berupa identitas, lama pemberian OAT preoperatif, tingkat neurologis preoperatif, kadar CRP dan LED preoperatif, dan data post-operatif saat follow up 2 bulan berupa tingkat neurologis, kadar CRP, dan kadar LED. Terdapat 58 pasien terdiri 25 laki-laki dan 33 perempuan, uji Kolmogorov-Smirnov menunjukkan bahwa terdapat perbedaan yang signifikan $(\mathrm{p}<0,05)$ pada tingkat neurologis post-operatif antara kelompok OAT $<2$ vs. $2-4$ minggu. Uji-t tidak berpasangan memperlihatkan bahwa kadar CRP dan LED post-operatif ditemukan bermakna secara signifikan $(\mathrm{p}<0,05)$. Tingkat neurologis postoperatif pada kelompok pemberian OAT preoperatif $<2$ minggu lebih baik bila dibandingkan dengan kelompok 2-4 minggu. Tindakan operasi lebih berperan penting terhadap hasil pengobatan pasien spondilitis tuberkulosis jika dibanding dengan lama pemberian OAT preoperatif.
\end{abstract}

Kata kunci: C-reactive protein (CRP), laju endap darah (LED), OAT preoperatif

Corespondence: Dr. Preodita Agradi, Department of Orthopaedic and Traumatology, Faculty of Medicine, Universitas Padjadjaran/Dr. Hasan Sadikin General Hospital Bandung, Jl. Pasteur No. 38 Bandung 40161, Email preodita@gmail. com 


\section{Introduction}

Spinal tuberculosis (TB) is the most dangerous bone tuberculosis infection due to destruction of the spine that may cause deformity and disability. ${ }^{1}$ The disease is prevalent in developing countries with malnutrition and high density populations. In endemic regions, such as Indonesia, the incidence of spinal tuberculosis is affected by several genetic factors that caused increased susceptibility to the disease, such as NRAMP1 gene polymorphism. ${ }^{2}$

Studies involving West Javanese subjects had found increased susceptibility towards spinal tuberculosis due to Fok1 vitamin D receptor gene polymorphisms and vitamin D deficiency. ${ }^{3}$

Patients with TB spondylitis and neurological deficits may have better outcome if surgery treatment was carried out in the early course of the disease. Preoperative anti TB drugs are an essential aspect in the management of TB spondylitis. Its' administration aims to prevent the dissemination of Mycobacterium TB, reduce the amount of toxins produced by the bacteria, reduce abscess formation, prevent relapse and recurrence. ${ }^{4}$ After the implementation of national health care insurance or BPJS in Indonesia, the cases of TB spondylitis had increased significantly and thus increasing the delay for receiving surgery treatment.

This causes the dilemma regarding the earlier surgical management of patients in order to achieve better outcome and to prevent TB infection to the operative personnel. Currently, there is no available consensus regarding the duration of preoperative anti TB drug administration.

Several studies had been giving the patients for 1-5 weeks of preoperative anti TB drug therapy. The effects of duration of preoperative anti-TB drug administration on outcome of TB spondylitis is still not yet clear. ${ }^{4-5}$ This study aimed to observe the effects of duration of preoperative anti TB drug on the outcome of patients with TB spondylitis.

\section{Methods}

The study was performed after acquiring ethical clearance from Health Research Ethics Committee Dr. Hasan Sadikin Hospital (RSHS) Bandung, number LB.04.01/A05/ EC/190/VII/2018. This retrospective study use secondary data from medical records of patients with TB spondylitis who received surgical treatment in RSHS from January 2014-May 2018, received preoperative anti TB drugs, and followed up for 2 months after the surgery in the outpatient clinic. The samples were collected using consecutive sampling method from target population, with the inclusion and exclusion criteria as follows:

Inclusion criteria, aged 15-70 years-old diagnosed with TB spondylitis with one of the following as surgical indication: Severe kyphotic deformity, Neurological deficits, Spine instability, Large abscess that required evacuation procedure. Severe pain, Patient had received preoperative anti TB (with the duration of $<2$ or $2-4$ weeks).

Exclusion criteria, previous history of anti TB therapy failure, such as relapse or noncompliance, using long-term corticosteroids. Allergic to anti TB drugs and received drugs other than the DOTS protocol. History of miliary TB. Other comorbidities, such as diabetes, rheumatism and autoimmune diseases. History of preoperative anti TB drug use for more than 4 weeks.

The data collected from the medical records were preoperative and post-operative data. Preoperative data consisted of patient identity, severity of neurological disability, C-reactive protein (CRP) and erythrocyte sedimentation rate (ESR) level, and duration of anti TB therapy. Post-operative data consisted of severity of neurological disability, CRP levels, and ESR during the follow-up period of 2 months. The patients were divided into two groups according to the duration of preoperative anti TB therapy: 1) Group I, duration of preoperative therapy of less than 2 weeks; 2) Group II, duration of preoperative therapy of 2-4 weeks.

The data were presented in descriptive 
Table 1 Characteristics of Study Subjects

\begin{tabular}{|c|c|c|c|}
\hline Variables & $\begin{array}{l}\text { All Patients } \\
\quad(n=58)\end{array}$ & $\begin{array}{c}\text { OAT }<2 \text { Weeks } \\
(n=27)\end{array}$ & $\begin{array}{c}\text { OAT 2-4 Weeks } \\
(n=31)\end{array}$ \\
\hline \multicolumn{4}{|l|}{ Age (years) } \\
\hline Mean \pm Std & $37.52 \pm 13.11$ & $36.61 \pm 14.45$ & $38.35 \pm 11.95$ \\
\hline Median & 38.00 & 36.5 & 38.0 \\
\hline Range (min-max) & $15.00-65.00$ & $15.00-65.00$ & $19.0-60.0$ \\
\hline \multicolumn{4}{|l|}{ Gender } \\
\hline Male & $25(43.1 \%)$ & $11(40.7 \%)$ & $14(45.2 \%)$ \\
\hline Female & $33(56.9 \%)$ & $16(59.3 \%)$ & $17(54.8 \%)$ \\
\hline \multicolumn{4}{|c|}{ Preoperative anti-TB duration (days) } \\
\hline Mean \pm Std & $16.86 \pm 6.412$ & $10.71 \pm 2.46$ & $22.42 \pm 2.61$ \\
\hline Median & 19.00 & 11.0 & 21.0 \\
\hline Range (min-max) & $4.00-28.00$ & $4.00-14.0$ & $18.00-28.00$ \\
\hline $\begin{array}{l}\text { Vertebra segment } \\
\text { Cervical } \\
\text { Thoracic } \\
\text { Thoracolumbar } \\
\text { Lumbar } \\
\text { Lumbosacral }\end{array}$ & $\begin{array}{c}4(6.9 \%) \\
35(60.3 \%) \\
6(10.3 \%) \\
12(20.7 \%) \\
1(1.7 \%)\end{array}$ & $\begin{array}{c}3(11.1 \%) \\
16(59.3 \%) \\
2(7.4 \%) \\
5(18.5 \%) \\
1(3.7 \%)\end{array}$ & $\begin{array}{c}1(3.2 \%) \\
19(61.3 \%) \\
4(12.9 \%) \\
7(22.6 \%) \\
0(0 \%)\end{array}$ \\
\hline \multicolumn{4}{|l|}{ Neurological disability (AIS) } \\
\hline A & $9(15.5 \%)$ & $4(14.8 \%)$ & $5(16.1 \%)$ \\
\hline B & $9(15.5 \%)$ & $5(18.5 \%)$ & $13(41.9 \%)$ \\
\hline $\mathrm{C}$ & $14(24.1 \%)$ & $7(25.9 \%)$ & $7(22.6 \%)$ \\
\hline $\mathrm{D}$ & $18(31.1 \%)$ & $7(25.9 \%)$ & $2(6.5 \%)$ \\
\hline $\mathrm{E}$ & $8(13.8 \%)$ & $4(14.9 \%)$ & $4(12.9 \%)$ \\
\hline \multicolumn{4}{|c|}{ Post-operative neurological disability (AIS) } \\
\hline A & $1(1.7 \%)$ & $0(0.0 \%)$ & $1(3.2 \%)$ \\
\hline B & $11(18.9 \%)$ & $1(3.7 \%)$ & $10(32.3 \%)$ \\
\hline $\mathrm{C}$ & $18(31.0 \%)$ & $7(25.9 \%)$ & $11(35.5 \%)$ \\
\hline $\mathrm{D}$ & $10(17.2 \%)$ & $7(25.9 \%)$ & $3(9.7 \%)$ \\
\hline E & $18(31.0 \%)$ & $12(44.4 \%)$ & $6(19.4 \%)$ \\
\hline \multicolumn{4}{|l|}{ Preoperative LED (mm/jam) } \\
\hline Mean \pm Std & $61.50 \pm 15.500$ & $62.32 \pm 12.183$ & $60.77 \pm 18.158$ \\
\hline Median & 60.00 & 60.50 & 60.00 \\
\hline Range (min-max) & $32.00-90.00$ & $44.00-88.00$ & $32.00-90.00$ \\
\hline \multicolumn{4}{|l|}{ Postoperative LED (mm/jam) } \\
\hline Mean \pm Std & $30.69 \pm 7.256$ & $28.82 \pm 6.037$ & $32.38 \pm 7.923$ \\
\hline Median & 30.00 & 28.00 & 33.00 \\
\hline Range (min-max) & $18.00-46.00$ & $21.00-45.00$ & $18.00-46.00$ \\
\hline \multicolumn{4}{|l|}{ Preoperative CRP (mg/dL) } \\
\hline Mean \pm Std & $22.62 \pm 17.980$ & $25.26 \pm 19.808$ & $20.23 \pm 16.108$ \\
\hline
\end{tabular}




\begin{tabular}{lccc}
\hline Median & 17.80 & 21.00 & 17.10 \\
Range (min-max) & $5.90-94.80$ & $5.90-94.80$ & $5.90-77.50$ \\
Postoperative CRP (mg/dL) & & & \\
Mean \pm Std & $8.42 \pm 4.035$ & $7.19 \pm 3.447$ & $9.54 \pm 4.252$ \\
Median & 7.60 & 6.00 & 8.50 \\
Range (min.-maks.) & $1.20-18.30$ & $1.20-15.30$ & $3.50-18.30$ \\
\hline
\end{tabular}

statistics in order to observe any characteristics and input to SPSS version 24.0 for Windows for further analysis. Numerical variables, such as patient age, duration of preoperative anti TB drugs, CRP and LED level would be presented in mean, standard deviation and range. For categorical variables, such as gender and degree of neurological disability would be presented in frequency distribution and percentages. Paired t-test and Mann-Whitney tests of significance were used. For categorical variables, Chi-Square test and KolmogorovSmirnov test were used. The data is deemed significant with a P-value $\leq 0.05$.

\section{Results}

The total of 58 patients who met the inclusion criteria was, divided into group I of $<2$ weeks of preoperative anti TB therapy (OAT)) and group II of 2-4 weeks of preoperative anti TB therapy (OAT: Table 1).

The degree of postoperative neurological disability on patients with previous use of preoperative anti TB drugs for less than 2 weeks was lower compared to groups given 2-4 weeks of preoperative anti TB drugs (Tabl e 2). Hypothesis testing using KolmogorovSmirnov test showed the p-values $<0.05$ in the variable of postoperative neurological disability; thus the difference between both groups were significant.

Futhermore, abnormal high values of preoperative ESR and CRP may indicate an active infection. Postoperative ESR and CRP values were decreased significantly after surgery. Both groups were analyzed using unpaired t-test. Both groups had significantly

\section{Table 2 Comparison of Pre- and Postoperative Degree of Neurological Disability Between} Group I and Group II

\begin{tabular}{lccc}
\hline Variables & $\begin{array}{c}\text { Duration of preoperative anti-TB therapy } \\
<2 \text { weeks } \\
\text { (n=27) }\end{array}$ & $\begin{array}{c}\mathbf{2 - 4} \text { weeks } \\
\text { (n=31) }\end{array}$ & p-value \\
& & & 0.276 \\
\hline Preoperative neurological disability (AIS) & $4(14.8 \%)$ & $5(16.1 \%)$ & \\
A & $5(18.5 \%)$ & $13(41.9 \%)$ & \\
B & $7(25.9 \%)$ & $7(22.6 \%)$ & \\
C & $7(25.9 \%)$ & $2(6.5 \%)$ & \\
D & $4(14.9 \%)$ & $4(12.9 \%)$ & \\
E & & & \\
Postoperative neurological disability (AIS) & $0(0.0 \%)$ & $1(3.2 \%)$ & \\
A & $1(3.7 \%)$ & $10(32.3 \%)$ & \\
B & $7(25.9 \%)$ & $11(35.5 \%)$ & \\
C & $7(25.9 \%)$ & $3(9.7 \%)$ & \\
D & $12(44.4 \%)$ & $6(19.4 \%)$ & \\
E & &
\end{tabular}


Table 3 Comparison of Preoperative and Postoperative ESR between Group I and II

\begin{tabular}{lccc}
\hline Variables & $\begin{array}{c}\text { Duration of preoperative anti-TB therapy } \\
\mathbf{<} \text { weeks } \\
(\mathbf{n = 2 7 )}\end{array}$ & $\begin{array}{c}\mathbf{2 - 4} \text { weeks } \\
(\mathbf{n = 3 1 )}\end{array}$ & p value \\
\hline Preoperative ESR & & & 0.700 \\
Mean \pm Std & $62.32 \pm 12.183$ & $60.77 \pm 18.158$ & \\
Median & 60.50 & 60.00 & \\
Range (min-max) & $44.00-88.00$ & $32.00-90.00$ & \\
Postoperative ESR & & & \\
Mean \pm Std & $28.82 \pm 6.037$ & $32.38 \pm 7.923$ & 0.705 \\
Median & 28.00 & 33.00 & \\
Range (min-max) & $21.00-45.00$ & $18.00-46.00$ & \\
P value & $0.05^{* *}$ & $0.05^{* *}$ & \\
\hline
\end{tabular}

lower $(\mathrm{p}<0.05)$ postoperative ESR and CRP levels compared to preoperative levels on both groups (Table 3; Table 4).

\section{Discussion}

TB spondylitis is a granulomatous infection of the vertebra that may cause serious morbidity due to damage of vertebra and spinal cord, therefore causing disability. The management of therapy with neurological deficits is mainly a combination of surgical and medical approach using anti TB drugs. Preoperative anti TB drugs is an essential aspect of spondylitis TB management; therapy duration, however, remain debatable, particularly on cases with neurological deficit that require immediate decompression surgery. The study observed any effects on the duration of preoperative anti TB drugs with the outcome of patients after surgery for spondylitis TB patients. The patients were divided into two groups based on the duration of preoperative anti TB therapy, the first group received $<2$ weeks of anti TB drugs and the second group received 2-4 weeks. All subjects were evaluated during the 2-month follow-up period, consisting of postoperative grade of neurological disability, ESR and CRP as parameters of ongoing infection. The 2 months after surgery

Table 4 Comparison of Preoperative and Postoperative CRP between Group I and Group II

\begin{tabular}{|c|c|c|c|}
\hline \multirow{3}{*}{ Variables } & \multicolumn{2}{|c|}{ Duration of pre-operative anti-TB therapy } & \multirow{3}{*}{ p value } \\
\hline & $<2$ weeks & 2-4 weeks & \\
\hline & $(n=27)$ & $(n=31)$ & \\
\hline Preoperative CRP & & & 0.194 \\
\hline Mean \pm Std & $25.26 \pm 19.808$ & $20.23 \pm 16.108$ & \\
\hline Median & 21.00 & 17.10 & \\
\hline Range (min-max) & $5.90-94.80$ & $5.90-77.50$ & \\
\hline \multicolumn{4}{|l|}{ Postoperative CRP } \\
\hline Mean \pm Std & $7.19 \pm 3.447$ & $9.54 \pm 4.252$ & 0.165 \\
\hline Median & 6.00 & 8.50 & \\
\hline Range (min-max) & $1.20-15.30$ & $3.50-18.30$ & \\
\hline$p$ value & $0.031^{* *}$ & $0.023^{* *}$ & \\
\hline
\end{tabular}


is essential since the follow up time was within a frame of intensive phase in the anti TB regimen. ${ }^{7}$ During the 2 month follow-up, no worsening of neurological disability and systemic infection were found in any of the patients enrolled in the study.

According to the study subject characteristics, TB spondylitis patients were predominantly in productive age, with mean age of 37.52 years. The distribution of spondylitis TB between both genders were 0.78:1 (male:female; Table 1). Our study was concurrent with the study by Wang $\mathrm{H}$. et al. in China that shows the range of patients from 2-82 years old with a mean age of 38.2 years and with an identical ratio of male to female. ${ }^{8}$ In this study, the most frequently affected vertebra segment were thoracic in 35 patients (60.3\%), lumbar in 12 patients (20.7\%), thoracolumbar in 6 patients $(10.3 \%)$, cervical in 4 patients $(6.9 \%)$ and lumbosacral in 6 patients (10.3\%). The results were identic with another study by Sharma A et al., ${ }^{9}$ in regards of the most prevalent affected vertebra segment, namely thoracic area (45.78\%), followed by thoracolumbar (27.52\%), lumbosacral (19.66\%) and cervical (6.92\%).

The results shown, postoperative neurological disability of spondylitis TB patients that had received preoperative TB drugs for $<2$ weeks are better vs. received them for 2-4 weeks, as it showed a significant $(p<0.05)$ difference between group I and group II in preoperative and postoperative scores of neurological disability. During the postoperative follow-up period of 2 months, the group with $<2$ weeks of therapy had increased ASIA grade ranging from 1 to 2 points on 23 out of 27 patients while on the preoperative therapy of 2-4 weeks, there were only increase of ASIA grade of 1 point in 16 out of 31 patients (Table 2). The cause of such findings may lie in the time to receive nerve decompression of spinal cord, in the first group, they had received earlier management: therefore, their outcome was better compared to the second group. Earlier management was associated with better chances of regeneration and healing of compressed nerves. Wang et al. discover that surgical management with anterior decompression is associated with better outcomes compared to conservative methods. ${ }^{10,11}$ A study by Loembe et al. ${ }^{12}$ in Gabon also discover similar results, that surgical treatment is associated with faster healing compared to conservative treatment.

Erythrocyte sedimentation rate (ESR) and CRP are important markers in monitoring the healing process of patients with infection. A study by Guo LX et al. reveal that ESR and CRP levels are reliable parameters in assessing response towards therapy and prognosis of patients with TB spondylitis. ${ }^{13,14}$ In both groups, it may be concluded that preoperative baseline ESR were above normal levels, although there were no significant baseline differences between both groups ( $p>0.05)$. After surgery, on the $2^{\text {nd }}$ month of follow-up, ESR levels decreased significantly on both groups $(p<0.05)$ and there were no systemic signs and symptoms of tuberculosis bacterial infection after the surgery.

Increased ESR levels were found in $90 \%$ of patients with TB spondylitis with mean ESR of 43-87 mm/hour. Increase of ESR may be associated with increased inflammatory processes. The ESR levels may decrease slowly, our results suggested that surgery had a role in decreasing ESR levels. The lack of complications during the study may also suggest that even during elevated ESR levels, the surgery may be performed safely. ${ }^{15}$ The results were concurrent with the previous study by Peng Zhang et al. ${ }^{6}$ that preoperative ESR levels that stay high after therapy may decrease after surgical management. No complications occurred after the surgery and no recurrence or signs of systemic TB infection were found during the study. The study also found that systemic infection was associated with the duration of preoperative anti TB therapy.

Elevated CRP levels were not significantly different in both group $(\mathrm{P}>0.05)$ in this study; although during the $2^{\text {nd }}$ month of postoperative follow-up, CRP levels had significantly decreased on both groups $(\mathrm{P}<0.05)$. Elevated levels of CRP were also found in $90 \%$ of 
spondylitis TB cases. The CRP levels decreased after the source of TB infection was removed through surgery and with optimal anti TB drugs therapy regimen. The results showed that the decrease of CRP post-operative was higher compared to postoperative ESR (Table 3; Table 4). These results were concurrent with a study by Cheung et al. ${ }^{16}$ that discover postoperative CRP on spine infection cases may return to baseline levels in faster rate compared to ESR levels in 3 months after surgery. The CRP level is a sensitive marker for inflammation, although it is not specific. Delaying the surgery by the basis of CRP levels may cause worse outcome. ${ }^{13}$

In this study, the authors suggested that patients with TB spondylitis and neurological deficits with other indications for surgery may not require preoperative anti TB therapy for 2-4 weeks. Several experts suggested that quality and rate of nerve healing may increase favorably compared to conservative methods. Decompression surgery may remove fibrous tissues that block the entrance of anti TB drugs. Therefore, it is not recommended to delay the treatment for several days in patients with such disabilities at least 2 weeks for anti TB therapy. This may be caused due to minimal concentration of anti TB drugs in the lesions due to sclerotic lesion border. Jain et al. suggest that pathological process of spinal TB consisted of infectious foci formation, sclerotic lesion border, osteoclasia and osteolysis. The sclerotic component predominantly occur on spinal TB (69.2-75\%). ${ }^{17,18}$ The findings are concurrent with Wang $\mathrm{Z}$ et al. that stated sclerotic vertebra in TB lesions may have a role in inhibition of drug entry to TB foci. ${ }^{19}$ Early surgery may have a more prominent role compared to conservative treatment, with better outcomes associated with earlier initiation of surgery.

\section{Conclusion}

In conclusion, the results of follow-up in patients with TB spondylitis with $<2$ weeks of preoperative anti TB therapy are better compared to those given 2-4 weeks of therapy.
The rate of nerve healing is faster in group given drugs for $<2$ weeks compared to the group given drugs for 2-4 weeks. Further studies, particularly in multicenter settings, longer follow-up duration and comprehensive evaluation may be required in order to further assess recurrence, bone fusion and implant loosening associated with the duration of preoperative anti TB drug therapy.

\section{References}

1. Tang $\mathrm{M}$, Zhang $\mathrm{H}$, Wang $\mathrm{Y}$, Guo C, Liu J. Treatment of spinal tuberculosis by debridement, interbody fusion and internal fixation via posterior approach only. Orthop Surg. 2016;8(1):89-93.

2. Tiksnadi B, Herman H. The NRAMP1 polymorphism as a risk factor for tuberculous spondylitis. Malay Orthopaedic J. 2013;7(1):25-9.

3. Ramdan A, Setiabudiawan B, Tiksnadi B. Plasma vitamin D level and vitamin D receptor genetic polymorphism of spinal tuberculosis susceptibility in West Java population, Indonesia: does it correlated. Global J Res Analys. 2017;6(2):68-9.

4. Ren HL, Jiang JM, Wang JX, Qu DB, Chen JT. Is duration of preoperative antituberculosis treatment a risk factor for postoperative relapse or non-healing of spinal tuberculosis?. Euro Spine J. 2016; 25(12):3875-83.

5. Yang L, Liu Z. Analysis and therapeutic schedule of the postoperative recurrence of bone tuberculosis. J Orthopaedic Surg Res. 2013;8:47.

6. Zhang P, Shen Y, Ding WY, Zhang W, Shang $Z$. The role of surgical timing in the treatment of thoracic and lumbar spinal tuberculosis. Archiv Orthopaedic Trauma Surg. 2014;134(2):167-72.

7. Rajasekaran S, Khandelwal G. Drug therapy in spinal tuberculosis. Euro Spine J. 2013;22(Suppl 4):587-93.

8. Wang H, Li C, Wang J, Zhang Z, Zhou Y. Characteristics of patients with spinal tuberculosis: seven-year experience of a teaching hospital in Southwest China. 
Intern orthopaedics. 2012;36(7):1429-34.

9. Sharma A, Chhabra HS, Chabra T, Mahajan R, Batra S, Sangondimath G. Demographics of tuberculosis of spine and factors affecting neurological improvement in patients suffering from tuberculosis of spine: a retrospective analysis of 312 cases. Spinal Cord. 2017;55(1):59-63.

10. WangZ,Wu Q, GengG.Anterior debridement and bone grafting with posterior singlesegment internal fixation for the treatment of mono-segmental spinal tuberculosis. Injury. 2013;44(2):253-7.

11. Wang X, Pang X, Wu P, Luo C, Shen X. Onestage anterior debridement, bone grafting and posterior instrumentation vs. single posterior debridement, bone grafting, and instrumentation for the treatment of thoracic and lumbar spinal tuberculosis. Euro Spine J. 2014;23(4):830-7.

12. Loembe PM, Mwanyombet-Ompounga L, Assengone-Zeh Y, Kengue-Lechiombeka PR. Early anterolateral surgery for tuberculosis of the lower cervical spine with neurological complications in adult. Our experience in Gabon. Neuro-Chirurgie. 2000;46(6):541-8.

13. Sudprasert W, Piyapromdee U, Lewsirirat S. Neurological recovery determined by c-reactive protein, erythrocyte sedimentation rate and two different posterior decompressive surgical procedures: a retrospective clinical study of patients with spinal tuberculosis. J Med Associat Thai. 2015;98(10):993-1000.

14. Guo LX, Ma YZ, Li HW, Xue HB, Peng W, Luo $\mathrm{XB}$. Variety of ESR and C-reactive protein levels during perioperative period in spinal TB. Zhongguo Gu Shang. 2010;23(3):2002.

15. An HS, Seldomridge JA. Spinal infections: diagnostic tests and imaging studies (1976-2007). Clin Orthopaedics Related Res. 2006;444:27-33.

16. Cheung WY, Luk KDK. Pyogenic spondylitis. Intern Orthopaedics. 2012;36(2):397404.

17. Jain AK. Tuberculosis of the spine: a fresh look at an old disease. J Bone Joint Surg. 2010;92(7):905-13.

18. Jain R, Sawhney S, Berry M. Computed tomography of vertebral tuberculosis: patterns of bone destruction. Clin Radiol 1993;47(3):196-9.

19. Ge Z, Wang Z, Wei M. Measurement of the concentration of three antituberculosis drugs in the focus of spinal tuberculosis. Euro Spine J. 2008;17(11):1482-7. 